\title{
CUTANEOUS NOCICEPTIVE TEST IN HORSES BY ALTERNATIVE METHOD
}

\author{
ALVES, José Edgard de Oliveira ${ }^{1}$ \\ VIEIRA, Evelyn Mayara Perrut ${ }^{2}$ \\ SILVEIRA, Máyra Dias ${ }^{3}$ \\ RICCI, Adiel $^{4}$ \\ SARTORI, Fábio ${ }^{4}$ \\ CATELLI, Marcelo Flores ${ }^{4}$
}

\begin{abstract}
SUMMARY: Pain is a complex phenomenon defined as an aversive sensory or emotional experience, where there is awareness of tissue damage or tissue integrity threat, with physiological and behavioral changes that aim to reduce or avoid occurrence of such damage. This study aimed to develop and evaluate an alternative low cost assessment method of the cutaneous nociceptive threshold in horses. The device used to assess the nociceptive threshold was constructed using an infrared $250 \mathrm{~W}, 220 \mathrm{~V}$ light bulb equipped with a mechanism to standardize the distance between the light bulb and the cutaneous surface of the animals. Six adult horses, males and females, were submitted to three evaluations. The results were submitted to analysis of variance (ANOVA) with Tukey's Multiple Comparison Test as post-test. No differences were observed among the evaluations $(p>0,05)$, indicating that this method fulfills the aim to emit a standard nociceptive stimulus able to trigger a regular and qualitatively similar response between the tested subjects. We concluded that the studied equipment can be constructed at an accessible cost and it has potential to be applied in models of experimental pain, although some improvements are needed.
\end{abstract}

Keywords: Pain. Analgesiometry. Experimental model. Thermal stimulation.

\section{TESTE NOCICEPTIVO CUTÂNEO EM EQUINOS ATRAVÉS DE MÉTODO ALTERNATIVO}

RESUMO: A dor é um fenômeno complexo definido como uma experiência sensorial ou emocional aversiva, em que haja consciência de dano tecidual ou ameaça à integridade de um tecido pelo animal, com alterações fisiológicas e comportamentais que visem reduzir ou evitar a ocorrência de tal dano. O presente estudo teve objetivo de desenvolver e avaliar um método alternativo de baixo custo para avaliação do limiar nociceptivo cutâneo em equinos. O equipamento para avaliação do limiar nociceptivo foi construído utilizando uma lâmpada infravermelha de $250 \mathrm{~W}$ e $220 \mathrm{~V}$ e dotado de aparato para padronização da distância entre a lâmpada e a superfície cutânea dos animais. Foram utilizados 6 equinos, machos e fêmeas adultos, os quais foram submetidos a três avaliações. Os resultados foram submetidos à análise de variância (ANOVA), adotando Tukey's Multiple Comparison Test como post-test. Não foram observadas diferenças $(p>0,05)$ entre as avaliações, o que indica que o método cumpre o objetivo de emitir um estímulo álgico padronizado capaz de eliciar uma resposta regular e qualitativamente semelhante entre os indivíduos testados. Conclui-se que o equipamento estudado mostrou-se capaz de ser construído a um preço acessível e potencialmente capaz de ser aplicado em modelos de dor experimental, ainda que necessários alguns aperfeiçoamentos.

Palavras-chave: Dor. Analgesiometria. Modelo experimental. Estimulação térmica.

\section{INTRODUCTION}

The International Association for the Study of Pain defines this phenomenon as an unpleasant sensory or emotional experience associated with real or potential tissue damage or

\footnotetext{
${ }^{1}$ Residente de Anestesiologia Veterinária da Universidade Estadual do Norte Fluminense. Universidade Estadual do Norte Fluminense Darcy Ribeiro

${ }^{2}$ Acadêmica de Medicina Veterinária da Universidade Severino Sombra.

${ }^{3}$ Médica Veterinária Autônoma

${ }^{4}$ Professor da Universidade Severino Sombra
} 
described in terms of such damage (LE BARS et al., 2001). However, in dealing with animals, the concept of pain can be quite complex. Muir (2010) suggests that the most appropriate setting for animal pain would be an aversive sensory and emotional experience, representing consciousness of damage or threat to the tissue integrity of the animal, with changes in physiology and animal behavior aimed at reducing or avoiding the occurrence of the damage, which reduces the probability of recurrence of a new injury and promotes the recovery of an eventual tissue damage. Thus, pain can be compared to an alarm which, when activated, has the role of helping to protect the organism by inducing behavioral changes that can reduce or avoid what is causing the pain, such as escaping, for example, which could result in the limitation of consequential damages to noxious stimuli (LE BARS et al., 2001).

The nociception is the term used to describe the neural process of transduction, transmission, modulation, projection and central perception of a real or potential tissue damaging stimulus and it begins by peripheral nociceptors, where the noxious stimulus is converted (transduction) to nervous impulses and the action potential is transmitted to the spinal cord. This route is dependent on the sensitivity and activity of the nociceptors, nociceptive neurons, and central nervous system state (MUIR, 2010).

Nociception evaluation tests consist in applying a measurable stimulus to a body part until a physiological or behavioral response occurs, when the triggering stimulus response is ceased (end point). These tests can be used experimentally to evaluate the analgesic efficacy of drugs and to determine the optimal doses for their clinical use. Therefore, the increase in the nociceptive threshold from the administration of a drug is considered indicative of an antinociceptive effect (LOVE et al., 2011).

Several methods for evaluating the nociceptive threshold have been described. Kamerling et al. (1985) described a model of experimental pain in horses which consists in applying a high intensity light focus on the skin surface to produce thermal stimulus and determine the nociceptive threshold by the latency time for an aversive response. This model has been widely adapted and reproduced in experiments using large animals (ZAMUR et al., 2011; SOUZA et al., 2002; ALMEIDA et al., 2005). Other evaluation tests of nociception, such as Von Frey filament, used for skin stimulation by Guirro et al. (2011), are also accepted methods in models of experimental pain in horses. The colic inducing balloon is a mechanical stimulus method to evaluate visceral pain, which involves inserting a balloon in the cecum, duodenum or the rectum, which is inflated, generating a nociceptive stimulus (LOVE et al., 2011).

Many of these methods are already established and used for many years in research activities involving horses. However, access to this type of equipment is still limited when dealing with studies with limited financial resources. For this reason, the present study aimed to 
develop and evaluate a low-cost alternative method for evaluation of cutaneous nociceptive threshold by limb withdrawal latency reflex in horses.

\section{MATERIAL AND METHODS}

This study was approved by the Universidade Severino Sombra Ethics in Animal Use Committee (CEUA - Comissão de Ética no Uso de Animais), protocol number 001/2014. The tests were performed at the Unidade de Ensino, Pesquisa e Extensão of the same institution, where six horses aged between 7 and 20 years were used, being two castrated males and four non-pregnant females, without defined breed and raised on extensive regimen.

The equipment for the tests fulfillment was constructed using a wooden frame to which an infrared light bulb ${ }^{5}(250 \mathrm{~W}, 220 \mathrm{~V})$ was attached, which was used for heat emission (Figures 1 and 2). Parallel to the light incidence direction, there is a metal rod equipped with markings for the purpose of standardizing the distance between the bulb and the skin surface of the metacarpophalangeal joint (fetlock area). Both the structures where the lamp is attached, as well as the metal rod, allow height adjustment to better match the possible variations of animal sizes. The light bulb was turned on from a simple switch triggered by an observer. The time interval to an aversive response to the thermal stimulus was timed from the moment the light bulb was turned on and terminated when the animal exhibited the limb withdrawal reflex.

Figure 1: Schematic drawing of the apparatus used for evaluation of nociceptive threshold by the latency to limb withdrawal reflex.

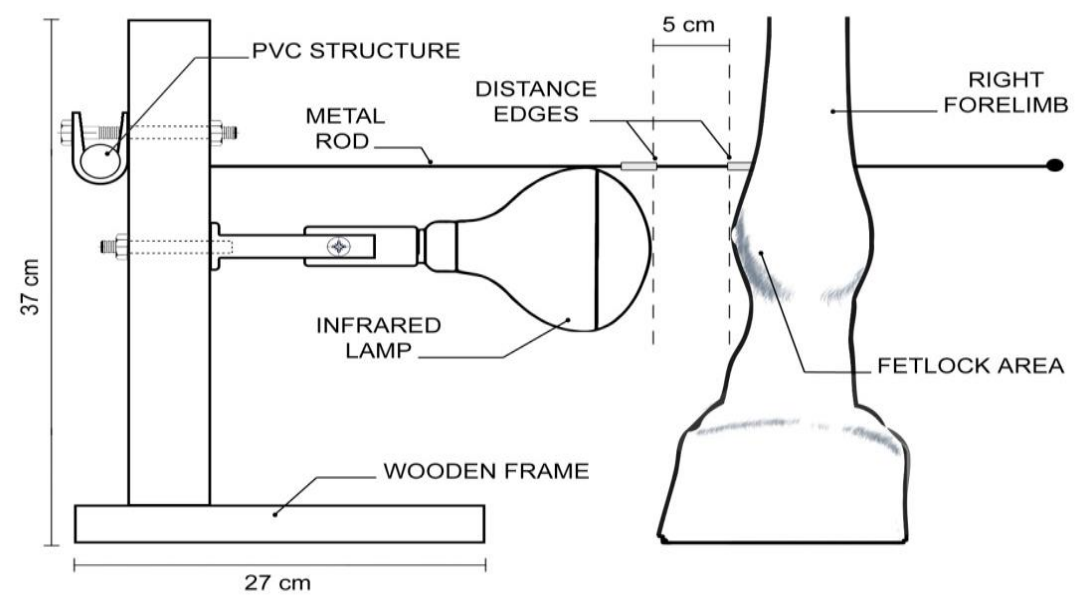

\footnotetext{
${ }^{5}$ Empalux $^{\circledR}$, IV22514 model, 250W, 220V.
} 
Three assessments were carried out (M1, M2 and M3), with one-hour intervals between each of them to qualify for the applicability and repeatability of the method. All assessments were made by the same observer. The chosen area for the incidence of light was the lateral side of the fetlock area of the right forelimb, which was shaved and dyed with washable black gouache paint (Figure 2), in such a way as to provide uniform light reflection and equal heat absorption by the skin in all animals.

Figure 2: Apparatus for performing the limb withdrawal latency reflex test.

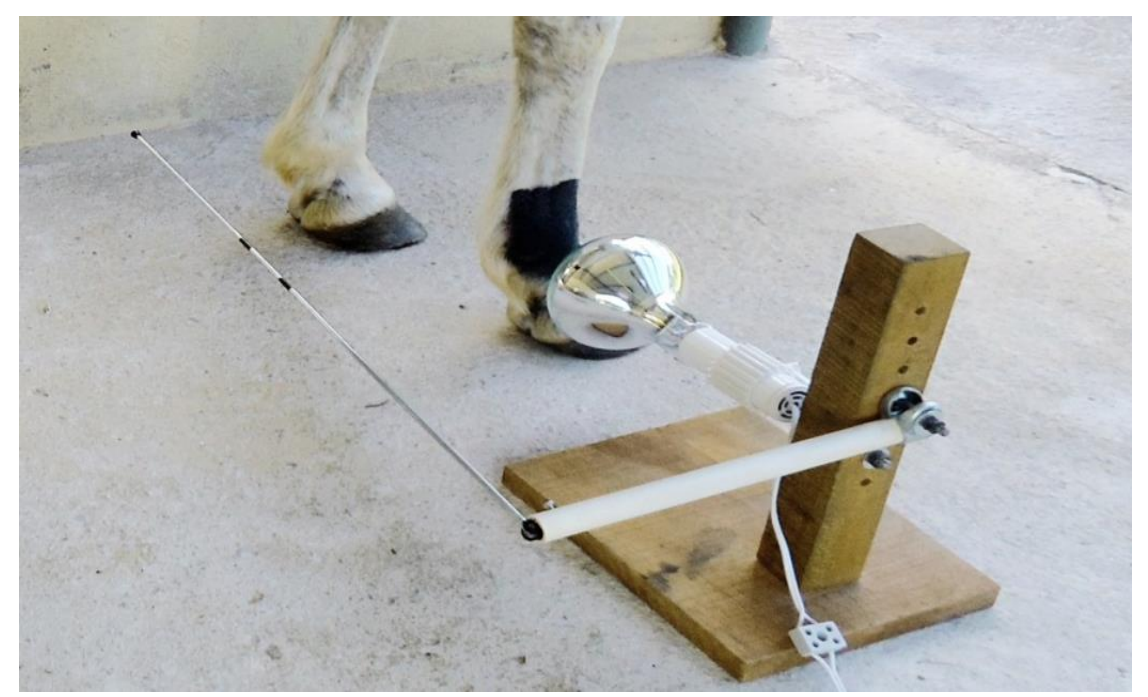

Subtitle: The apparatus was composed of a light bulb attached to a wooden frame, from which a PVC structure is laterally projected to hold a metal rod that extends parallel to the infrared light incidence direction with markings which enable to set a distance of 5 centimeters between the light bulb and the fetlock area cutaneous surface.

The results were expressed as the mean \pm the standard error of the mean (SEM) and comparisons between evaluations were made by analysis of variance (ANOVA) followed by Tukey's Multiple Comparison Test with significance level of 5\% $(p<0.05)$. The calculations and graphics were made using the GraphPad Prism $5^{6}$ software.

\section{RESULTS AND DISCUSSION}

Comparing the means obtained on assessments performed in our tests, no differences were observed $(p>0.05)$ in any of the periods studied, as can be observed in graph 1. 
Graph 1. Means \pm SEM of the limb withdrawal latency reflex time in the assessments.

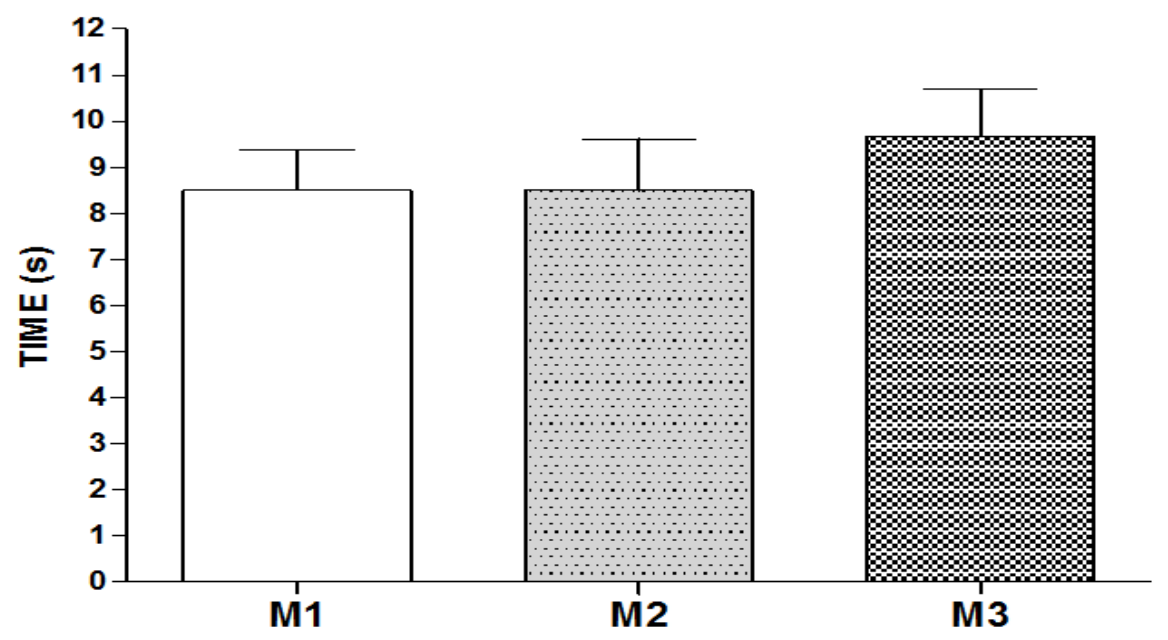

Subtitle: Time in seconds. M1: First assessment (basal); M2: Second assessment (after 60 minutes); M3: Last assessment (after 120 minutes).

The mean of the results obtained in M3 $(9.6 \pm 1.0)$ was virtually higher than the values found in the two initial assessments, where we obtained means of $8.5 \pm 0.8$ in M1 and $8.5 \pm 1.1$ in M2. However, despite this slight difference in the absolute values of the tests, these means did not differ $(p=0.6507)$ when analyzed by ANOVA. This suggests that the experimental pain model studied here fulfills what it proposes in providing a standard stimulus for all the tested animals, once the observed responses and the latency reflex periods were presented in a regular manner in all animals and moments studied, which corroborates Kamerling et al. (1985), who state, as important characteristics of an effective model, the existence of a readily identifiable and qualitatively similar response between animals to which the test is applied, stable over time and capable of being reproduced in other related experiments and that does not cause significant tissue damage to animals exposed to repeated tests.

Other studies adopting models of experimental pain with thermal stimulation in horses limited the exposure time to the spotlight (cut-off time) in 10 seconds in the essays (SOUZA et al., 2002; ALMEIDA et al., 2005). This is adopted in order to avoid the occurrence of tissue injuries. In cows, Almeida et al. (2005) adopted a cut-off time of 20 seconds. However, the equipment used by these authors is susceptible to modifications and adaptations. Light bulb types and intensity of heat emitted by these may vary considerably in these studies. In our experiments, no tissue damage was observed in any of the animals tested. Le Bars et al. (2001), mentions that, in experiments involving the study of pain in conscious animals, the method used should be applied by the researcher to himself, and this should occur whenever possible, in most of the cases of non-invasive stimuli. Applying this principle, we conclude that exposures up to 30 
seconds under the light would not be capable of causing tissue damage, setting a 20 seconds cutoff time, starting from the switching of the light bulb.

In experimental designs with multiple repetitions, it is possible that the animals develop conditioned reflexes to the lighting of the lamp or even the positioning of the apparatus with the light bulb laterally to the limb, which interferes directly in the results of the study. According to Zilio (2010), the conditioned reflex prepares the body for the presentation of an original stimulus.

In an example applied to our experiment, it is said that the ratio of heat stimuli - limb withdrawal reflex is an unconditioned response, unlike ratio of light - limb withdrawal, which only occur after several heat presentations associated with light, the second assertion would be able to elicit limb withdrawal response. A possible solution for this problem would be to apply the method in a completely randomized design, where the animals would be used in the tests only once. Another strategy aiming to prevent the occurrence of conditioned reflexes is described by Souza et al. (2002), who, in their experiments, used an auxiliary non-heat radiant light bulb which was activated at random for the tested animals not to associate the light with the generated thermal stimulus. Complementing this technique, the use of blinders - commonly used as an accessory to limit side viewing - in order to improve the dissociation of the animal and the ambience, could also be a relevant device to obtain more accurate results.

\section{CONCLUSIONS}

The method used in our experiments respects the ethical principles of research, promoting a regular and acute pain stimulus, which is the smallest required to elicit a response, and this response, in turn, respects the particularities of the studied species; It proved possible to be built at a budget price, since it basically uses an infrared light bulb; and potentially capable of being used in models of experimental pain in horses, though some improvements are necessary.

\section{ACKNOWLEDGEMENTS}

The authors thank the USS/FUSVE for scientific initiation scholarship granted to carry out this project.

\section{REFERENCES}

ALMEIDA, R. M.et al. Avaliação dos efeitos do amitraz por via epidural em vacas. Brazilian Journal of Veterinary Research and Animal Science, v. 42, n. 6, p. 419-428, 2005. 
GUIRRO, E. C. B. P.et al. Efeitos comportamental, clínico e analgésico promovidos pela injeção epidural preventiva de morfina, xilazina ou clonidina, em equinos. Ciência Rural, v. 41, n. 10, p. 1790-1796, 2001.

KAMERLING, S. G.et al. A method for studying cutaneous pain perception and analgesia in horses. Journal of Pharmacological Methods, v. 13, p. 267-274, 1985.

LE BARS, D.; GOZARIU, M; CADDEN, S. W. Animal Models of Nociception.

Pharmacological Reviews, v. 53, n. 4, p. 597-652, 2001.

LOVE, E. J.; MURRELL J.; WHAY, H. R. Thermal and mechanical nociceptive threshold testing in horses: a review. Veterinary Anaesthesia and Analgesia, v. 38, p. 3-14, 2011.

MUIR, W. W. Pain: Mechanisms and Management in Horses. Veterinary Clinics of North America: Equine Practice, v. 26, p. 467-480, 2010.

SOUZA, A. H.et al. Efeito da injeção subcutânea de doses baixas de cetamina em equinos. Ars Veterinaria, v. 18, n. 3, p. 223-230, 2002.

ZAMUR, G.et al. Comparação dos efeitos sedativos e/ou antinociceptivos dos tranquilizantes acepromazina, levomepromazina e azaperone em equinos. Ars Veterinaria, v. 27, n. 4, p. 231240, 2011.

ZILIO, D. A natureza comportamental da mente: behaviorismo radical e filosofia da mente. São Paulo: Editora UNESP; São Paulo: Cultura Acadêmica, 2010. 294 p. 
